\title{
The Life and Work of Mary-Anne Elizabeth Plaatjies-Van Huffel in Church and Society with specific Reference to the Confession of Belhar
}

\author{
Johan M van der Merwe \\ http://orcid.org/0000-0002-7678-5452 \\ University of Pretoria, South Africa \\ johan.vdmerwe@up.ac.za
}

\section{Abstract}

The untimely death of Mary-Anne Elizabeth Plaatjies-Van Huffel challenges everybody who knew her to reflect on her life and work. One of the outstanding attributes of Plaatjies-Van Huffel was the way in which she "lived" the Confession of Belhar. To her it was much more than a theological document. It guided her life, was the lens through which she looked at church and society and, in the process, became personified in her life and work. This is the focus of the article. It starts off with a short overview of the life of Plaatjies-Van Huffel before it gives a short description of the importance of the Confession of Belhar. How the life of Plaatjies-Van Huffel and the Belhar Confession became inseparable is then described through the three critical areas which are addressed by the Confession, namely unity, social justice and reconciliation. Examples of her leadership in the reunification process between the Dutch Reformed Church (DRC) and the Uniting Reformed Church in Southern Africa (URCSA), and press statements on social justice and reconciliation are then used to illustrate how the Confession was embodied by Plaatjies-Van Huffel.

Keywords: Mary-Anne Elizabeth Plaatjies-Van Huffel; Confession of Belhar; unity; social justice; reconciliation

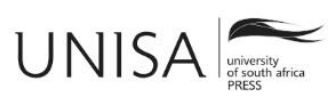




\section{Introduction: Mary-Anne Plaatjies-Van Huffel}

I hope that I am a vision of hope for women in and outside of the church for their own careers. My success story must be the success story of all women. ${ }^{1}$

This comment by Mary-Anne Elizabeth Plaatjies-Van Huffel, after she was elected as a female church leader to the highest decision-making structures of URCSA, is an indication of her visionary leadership that changed not only URCSA but church and society in South Africa.

Mary-Anne Elizabeth Plaatjies was born on 15 December 1959 in Prieska in the Northern Cape. She matriculated in 1977 at Bergrivier Senior Secondary School in Wellington in the Boland. After qualifying and working as a teacher she enrolled at the University of the Western Cape to study theology in 1986. She was licensed in 1992 and became the first women to be ordained as a minister in the Dutch Reformed Mission Church. $^{2}$ After her licensing, Plaatjies-Van Huffel was called to the combination congregation of Robertson-Robertson East in the Western Cape where she was ordained as a minister. The historical importance of her ordination did not go unnoticed. Jane Dempsey Douglas, president of the World Alliance of Reformed Churches, wrote in a personal letter:

We want you to know how important it is to all of the churches of the World Alliance of Churches, that your church has now opened its ministry to women. We realise that it is not easy for you as the first ordained women pastor, but it is an exciting opportunity to which the Holy Spirit has led you. We know that God will continue to strengthen you for the tasks which lie ahead. I was particularly interested to notice the text from the Bible on which Dr Boesak preached the ordination sermon. The story from the Book of Numbers about the inheritance of the daughters is a favourite one for women at Princeton Theological Seminary. ${ }^{3}$

Plaatjies-Van Huffel was appointed as a temporary lecturer in systematic theology at Hugenote Kollege in $2007^{4}$ before becoming an associate professor in ecclesiology and church polity at the University of Stellenbosch in $2010 .^{5}$ She was also called as cominister in the congregation of Scottsdene in Kraaifontein in the Western Cape in 2010. Plaatjies-Van Huffel was an astute academic who completed two doctorate degrees. The first was a DTh at Unisa under the supervision of Prof. Christina Landman with the title: Vroue in die Teologiese Antropologie in die Afrikaanse Gereformeerde Tradisie, which she completed in 2003. ${ }^{6}$ The second doctorate was a $\mathrm{PhD}$ at the University of Pretoria under the supervision of Prof. Johan M van der Merwe, with the title: Die Doleansie

1 C. Flaendorp, "The Life and Times of Professor Mary-Anne Plaatjies-Van Huffel: A Transformative Church Leader in Sub-Saharan Africa." Studia Historiae Ecclesiasticae 40 (1): 59, 2014.

2 Flaendorp, 53.

3 Flaendorp, 55.

4 https://sun.academia.edu/MaryAnnPlaatjiesvanHuffel/CurriculumVitae.

5 https://sun.academia.edu/MaryAnnPlaatjiesvanHuffel/CurriculumVitae.

6 http://uir.unisa.ac.za/handle/10500/1190. 
Kerkreg en Kerkregering van die Nederduits Gereformeerde Sendingkerke en die $V G K S A$, which she completed in $2008 .{ }^{7}$ Her theological framework was, according to Flaendorp, founded on three pillars: i) a theology of dignity especially towards the vulnerable groups; ii) the theological disciplines of church history and church polity; and iii) a theology of ecology and justice. ${ }^{8}$

Plaatjies-Van Huffel also played an important leadership role in the Uniting Reformed Church in Southern Africa (URCSA). She was elected as actuarius of the Cape synod of URCSA in 2002. In 2008 she was elected as vice-moderator of the general synod of URCSA, and in 2012 she was elected as moderator of the general synod of URCSA, becoming the first woman to be elected as moderator. In 2013, Plaatjies-Van Huffel was elected as one of the vice-presidents of the World Council of Churches, becoming the president for Africa. ${ }^{9}$

The role that Plaatjies-Van Huffel played was summarised by Prof. Reggie Nel, Dean of the Faculty of Theology at the University of Stellenbosch, when he said:

While she has been a staunch activist for causes like black theology, women's rights and transformation on many levels, and has represented our continent in prominent positions including in the World Communion of Reformed Churches and the World Council of Churches, she has also been a passionate church historian, church law expert and pedagogue. Her career at the Faculty of Theology at Stellenbosch University commenced recently, but she made an indelible impression in her field, and in the hearts and minds of her colleagues and students. She was the first black woman to be promoted to full professor at the Faculty of Theology at Stellenbosch University and this remarkable achievement would have been recognised at her inaugural lecture as Professor in Ecclesiology later this year. ${ }^{10}$

\section{Plaatjies-Van Huffel and the Original Text of the Confession of Belhar}

Although Plaatjies-Van Huffel knew the Belhar Confession by heart and signed it at her licensing in 1992, she had an important encounter with the original text of the Belhar Confession in 2014. ${ }^{11}$ She wrote as follows: "A few months ago I held in my hand for the first time the original texts of the Belhar Confession, handwritten in green and red ink by Prof. Dirkie Smit, one of the co-drafters of the Belhar Confession. Until recently, the original documents were never disclosed. Smit kept the original draft of the Belhar Confession in a drawer in his study for more than thirty years." ${ }^{12}$ And further: "The file,

7 http://upetd.up.ac.za/thesis/available/etd-04022009-190218/.

8 Flaendorp, 58.

9 Flaendorp, 54.

10 Theology/Corporate Communication 19/05/2020. "SU Mourns Passing of Prof. Mary-Anne PlaatjiesVan Huffel.” http://www.sun.ac.za/english/Lists/news/DispForm.aspx?ID=7366, 2020.

11 The author of this article received the pictures of the original text in the handwriting of Prof. Dirkie Smit from Prof. Dr Mary-Anne E. Plaatjies-Van Huffel. He was also witness to her excitement on receiving the original document.

12 Plaatjies-Van Huffel, "The Belhar Confession in its Historical Context.” NGTT 55 (1): 302, 2014. 
which Dirkie Smit handed to me, consists of the early handwritten notes, the first draft, the first English and German translations of the Belhar Confession as well as the accompanying letter. Much had changed in the final draft before it was tabled at the synod. The insertions, changes, deletions and even omissions by the commission can easily be seen in the original handwritten documents. The handwritten text was typed by Ms Pontac, the administrative clerk in Prof. Jaap Durand's office at the University of the Western Cape (UWC)."13
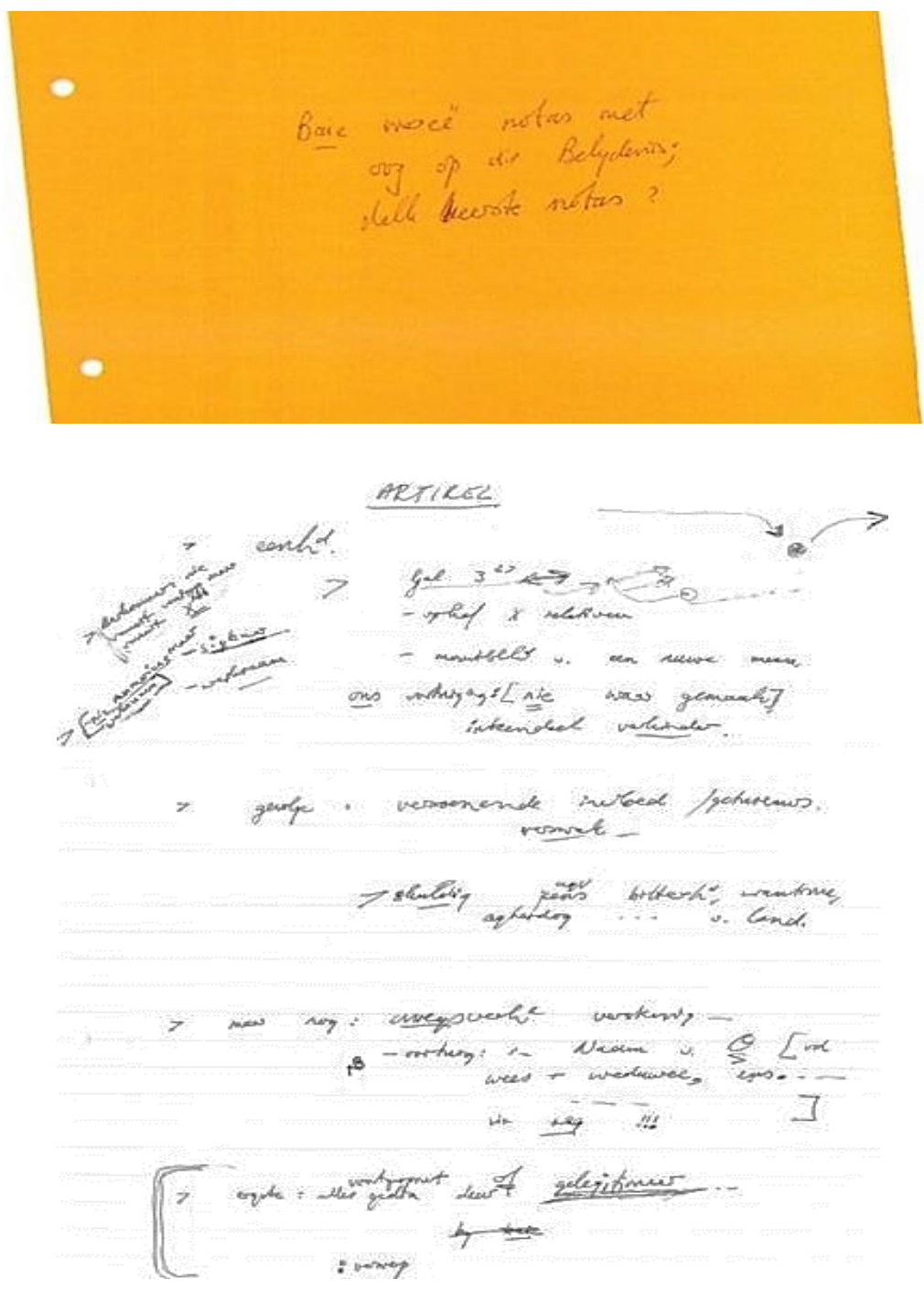

13 Plaatjies-Van Huffel, 302, 2014. 


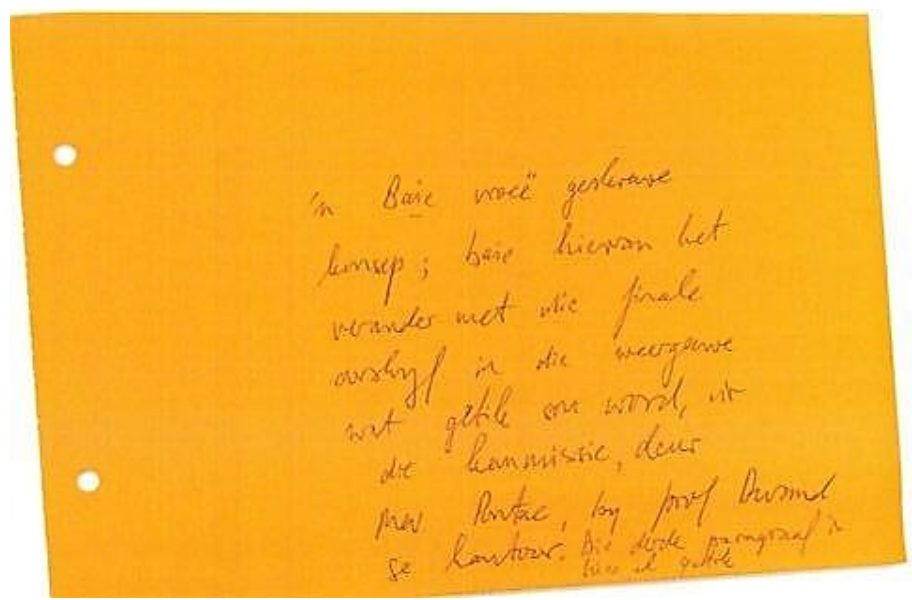

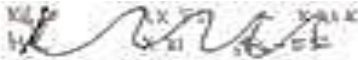

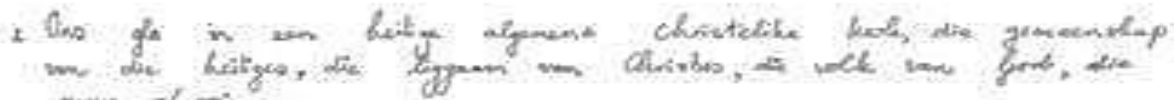
nuve Hypin:

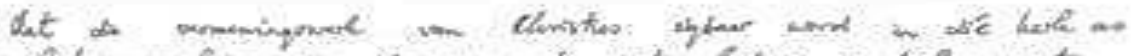

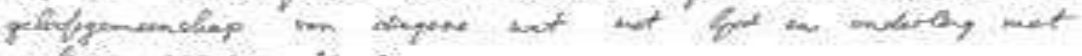
melens seroos is 5

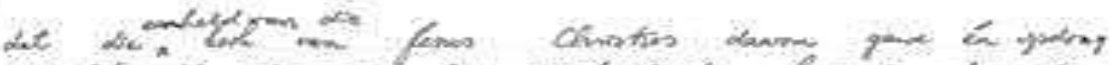

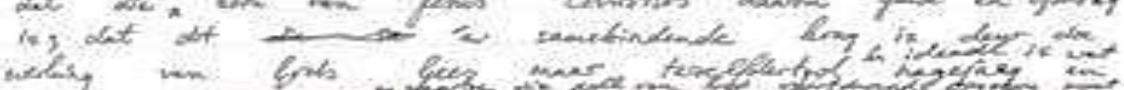

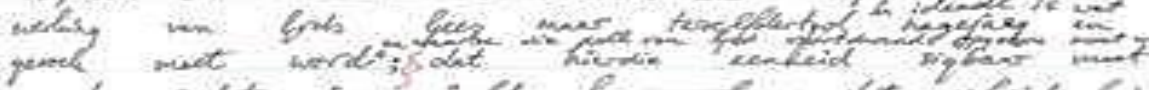

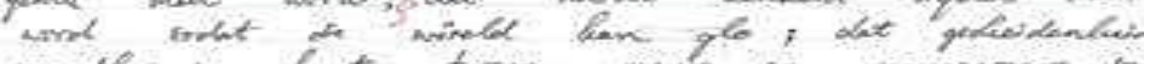

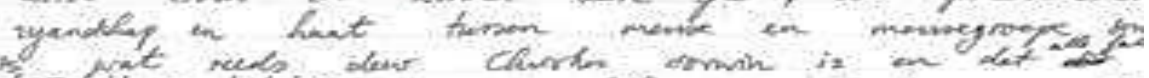

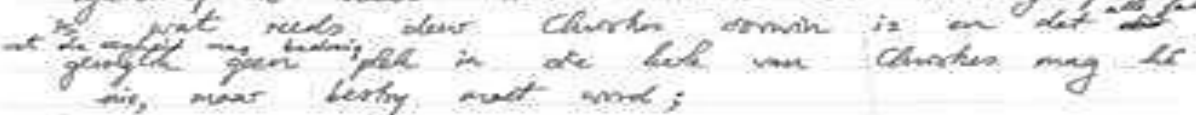

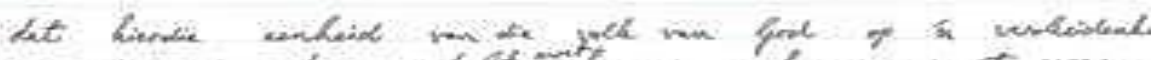

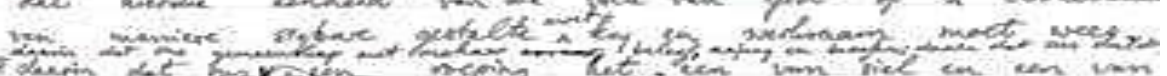

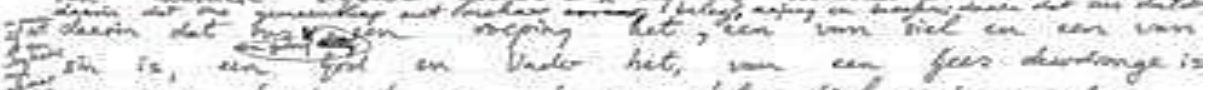

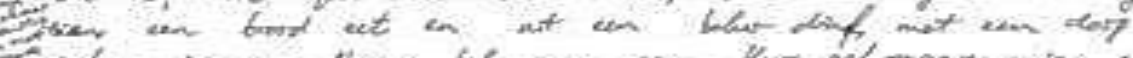

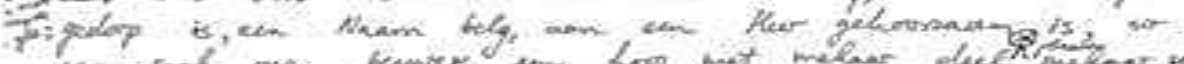

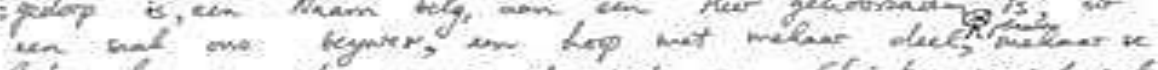

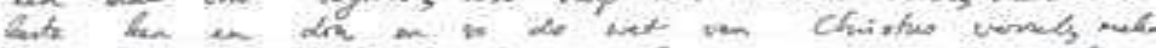

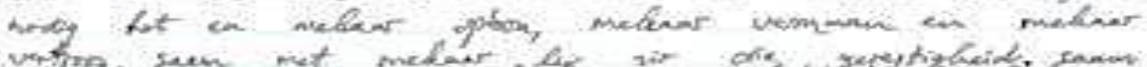

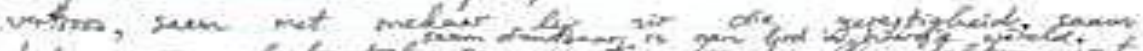

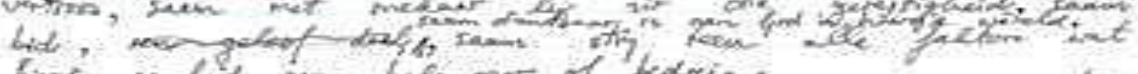

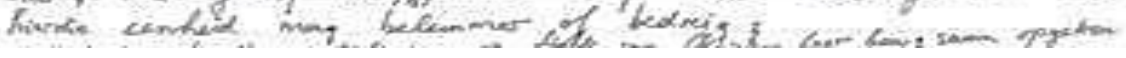




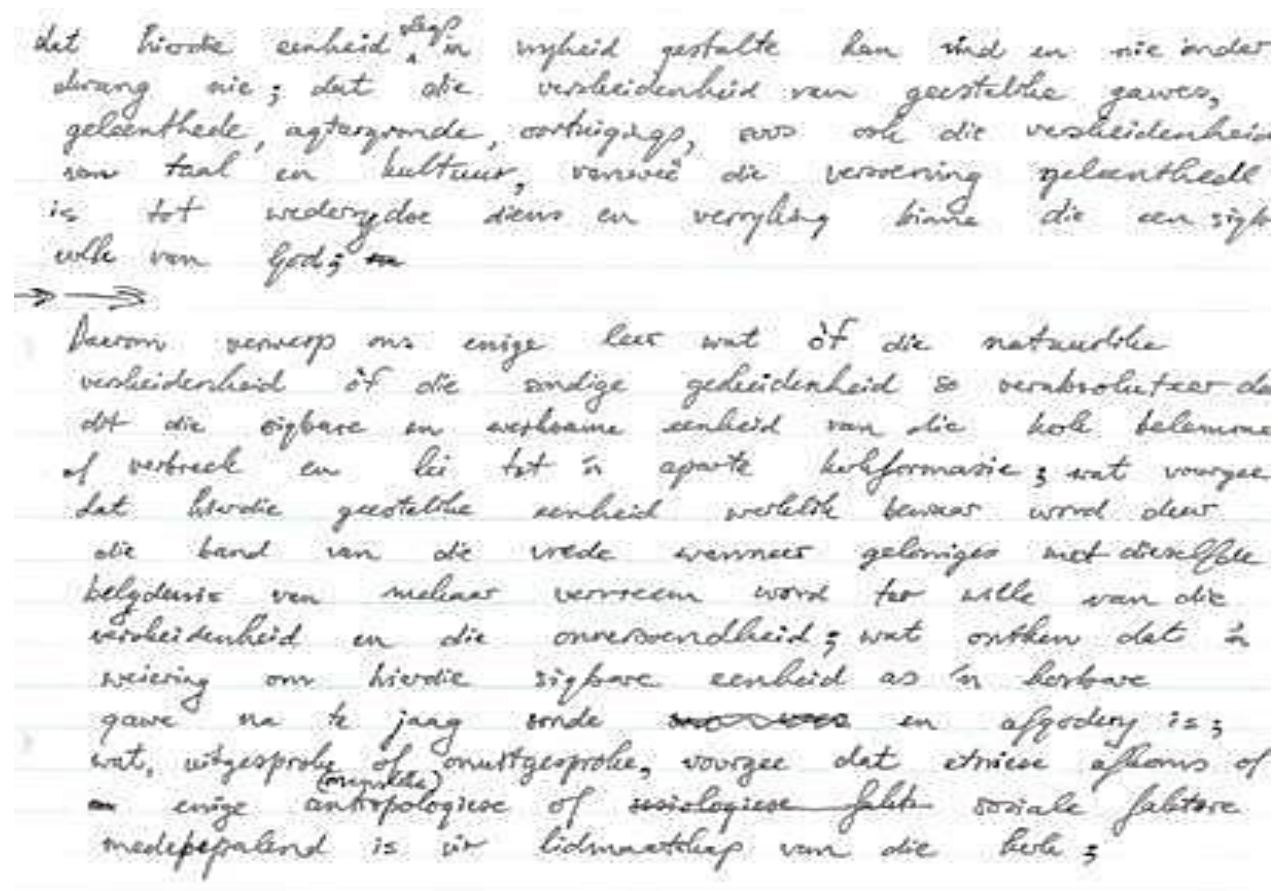

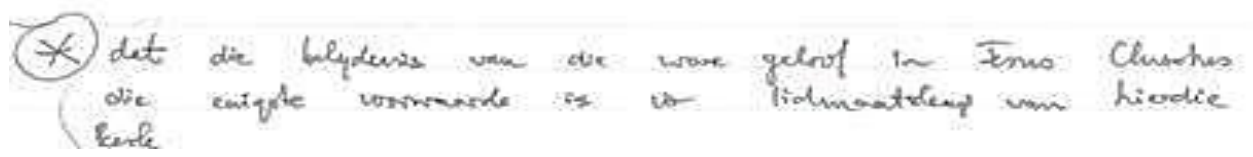
taarom ververp ons evige beer wet in naam van dis evangetie of die nil van feod die gedwonge sleciding, van manse op gond van ras en Hew is to 4 situasie sanbionces en dourdew die bedionhy en belas van die verooning in Chisties by corbaat belemms en onthragiog.

Figures 1-5: Composite pictures of the original text of the Confession of Belhar

Source: Van der Merwe (2020). Personal collection.

This original document had a huge influence on Plaatjies-Van Huffel and triggered, according to her, certain important questions. She wrote:

Suddenly I had to ask myself the very same questions which researchers ask themselves concerning historical texts. What is the context? What is the setting? (Sitz im Leben?). Where, why and when was it written? Who is the author and what is her or his place, 
position, role, reputation, status in society? What kind of document is it? What point is the author trying to make? What was the motive (purpose) of the author(s) in preparing it? Who was it written for? What is known about the audience? What is the argument and strategy utilised by the authors to achieve their goals ${ }^{14}$

These questions serve as indicators of the important role which the Confession of Belhar played in her life.

Plaatjies-Van Huffel did not only ask the questions. She answered the questions in two ways: Firstly, with numerous scholarly articles on the Confession of Belhar ${ }^{15}$ and a very important book which she co-edited with Prof. Leepo Modise. The title of the book, Belhar Confession: The Embracing Confession for Church and Society ${ }^{16}$ is an important indicator of how the Confession influenced her outlook on church and society. The book gives a chronological outline of the story of Belhar and addresses important theological and ethical themes regarding the Belhar Confession, such as: conversion towards radical inclusivity; yearning for a just and inclusive society; the Belhar Confession and compassionate justice, to name just a few. The second way in which Plaatjies-Van Huffel answered to the questions posed by the Confession of Belhar was her leadership in church and society. The latter is the focus of this article.

\section{Important Content of the Confession that Changed Everything}

In order to understand how the Belhar Confession influenced the life of Plaatjies-Van Huffel and how she used it as a lens through which she looked at church and society, a short overview of the content of the Confession is necessary.

The Confession of Belhar addresses three critical areas in the South African context, namely church unity, reconciliation and justice. On unity it states "that unity is, therefore, both a gift and an obligation for the church of Jesus Christ"; and further "that this unity must become visible so that the world may believe that separation, enmity and hatred between people and groups is sin which Christ has already conquered, and accordingly that anything which threatens this unity may have no place in the church and must be resisted." 17 On reconciliation it stated: "We believe that God has entrusted the church with the message of reconciliation in and through Jesus Christ"18 and:

14 Plaatjies-Van Huffel, 302, 2014.

15 Reading the Belhar Confession as historical text. In Reformed Churches in South Africa and the struggle for justice - Remembering 1960-1990 (Editors: R. R. Vosloo and Mary-Anne E. PlaatjiesVan Huffel), Sun Press, 2013 (3). The Belhar Confession in its Historical Context, 2014, NGTT 55 (1) (4) The Belhar Confession: Born in the struggle against apartheid in Southern Africa, guiding light today Studia Historicae Ecclesiasticae 2013. http://wwwuir.unisa.ac.za/bitstream/handle/10500/9977.

16 The book with Mary-Anne E. Plaatjies-Van Huffel and Leepo Modise as editors was published by African Sun Media in 2017.

17 URCSA. Confession of Belhar, www.vgksa.org.za.

18 URCSA. Confession of Belhar. 
Therefore, we reject any doctrine which, in such a situation sanctions in the name of the gospel or of the will of God the forced separation of people on the grounds of race and colour and thereby in advance obstructs and weakens the ministry and experience of reconciliation in Christ.

On justice it stated:

We believe that God has revealed God self as the One who wishes to bring about justice and true peace on earth; that in a world full of injustice and enmity God is in a special way the God of the destitute, the poor and the wronged and that God calls the church to follow in this. ... Therefore, we reject any ideology which would legitimate forms of injustice and any doctrine which is unwilling to resist such an ideology in the name of the gospel. ${ }^{19}$

The intent of the Confession is described in the accompanying letter as follows: "This Confession is not aimed at specific people or groups of people or a church or churches. We proclaim it against a false doctrine, against an ideological distortion that threatens the gospel itself in our church and our country"; and "Therefore this Confession must be seen as a call to a continuous process of soul-searching together, a joint wrestling with the issues, and a readiness to repent in the name of our Lord Jesus Christ in a broken world. It is certainly not intended as an act of self-justification and intolerance, for that would disqualify us in the very act of preaching to others." 20

The importance of the content of the Confession and the intent of the accompanying letter speak for itself. Prof. S. T. Kgatla confirmed this when he said:

The Belhar Confession was called for by the political and cultural movement, operating inside and outside the church, of the denial of human rights to the black citizens of the country. The church had to come up with a confession that responded to the challenges of apartheid. The church had a conviction that the promises and demands of the Gospel were needed by both those who propagated injustices against black fellow citizens and the victims as well. The Belhar Confession was an appropriate response by and a voice of the black Christians within the DRC Family in South Africa. It was a credible response to and critique of the ideologization of Christianity in the core beliefs of the white dominant culture of the time. It responded to the destructive experience of being dominated and the incriminating experience of being the one who dominated and benefited from the domination of the other. It brought necessary clarification to hard and pressing theological questions of the time. ${ }^{21}$

Kgatla again stressed the importance of the Confession of Belhar when looking forward. He said: "En-route to re-unification of the DRC family, the Belhar Confession remains our guiding resource for cooperation, restoration, revitalisation, and reconciliation.

19 URCSA. Confession of Belhar.

20 URCSA. Confession of Belhar, Accompanying letter, www.vgksa.org.za.

21 S. T. Kgatla, "The Belhar Confession Yesterday, Today and Tomorrow," www.ngkok.co.za. 2013. 
Thus, the Belhar Confession can never become irrelevant to our existential issues. ${ }^{~} 22$ It is clear from the words of Kgatla that the three critical areas addressed by the Confession, namely unity, social justice, and reconciliation indicated the way forward. It is these areas which became focus areas in the life of Plaatjies-Van Huffel.

The remainder of the article will, therefore, show how these three focus areas of the Confession of Belhar played an important role in the life and work of Plaatjies-Van Huffel.

\section{Unity}

"I am glad that the synod decided to revoke the decision on the moratorium about discussions on Church Unity. Now we can dream together on how the church can contribute to make the country a better place for all. ${ }^{23}$ These words of Plaatjies-Van Huffel, after she was elected as moderator of the general synod of URCSA in 2012, are an indication of how important church unity was to her. Plaatjies-Van Huffel referred to the important watershed decision that the general synod of URCSA took in 2012 under her direct leadership as moderator. The decision was as follows:

1. URCSA is called by God to exercise a prophetic voice in the world and in particular in Southern Africa. In its mandate URCSA is guided by the principles of honesty, integrity and uprightness as enjoined by the Confession of Belhar. URCSA acknowledges and supports whatever effort which is authentic as guided by the Scriptures.

2. URCSA General Synod sitting at Okahandja resolves to note and appreciates the breakthrough developments within the DRC recent General Synod to start a process in the Church Orderly way to accept the Belhar Confession.

3. URCSA steps forward and stretches out its hand to the DRC to re-enter the unity process again. It revokes its 2008 decision on a moratorium on all three churches within the DRC family of churches as the other two churches too showed their willingness to take part in the ongoing process of unity.

4. The General Synod instructs all regional synods, presbyteries and congregations to engage their counterparts within the DRC, DRCA and RCA with sincerity but firmly as guided by the spirit of the Belhar Confession on all matters that the decision of the lifting of the moratorium will apply.

5. The General Synod acknowledges with thanks the role played by the WCRC and especially the role of Dr Jerry Pillay in the journey of our churches.

6. The General Synod acknowledges that God can and will always surprise us in the journey to unity to the glory of God.

22 Kgatla, 6.

23 Oosthuizen, J. Own translation. "Die Vrou met Leeuemoed Lei die VGK." Die Kerkbode 19 Oktober $2012,3$. 
7. The General Synod accepts the Memorandum of Understanding developed by the two executives during a meeting of 25-26 July 2012, with the amendments, as basis for the way forward under the guidance of the WCRC. ${ }^{24}$

This decision opened the way for renewed discussions on unity within the family of Dutch Reformed Churches in South Africa.

Plaatjies-Van Huffel did not only play a leading role during the general synod of 2012, but she also had a huge influence on the way forward. ${ }^{25}$ Although important discussions ${ }^{26}$ on unity between the two churches ${ }^{27}$ had started before her election in 2012, her leadership and passion for unity gave new momentum to the process. The outcome of several meetings ${ }^{28}$ between URCSA and the DRC was the signing of a Memorandum of Agreement ${ }^{29}$ between the two churches on 10 April 2013. The statement issued by the executives after the meeting on 9-10 April 2013, where the Memorandum of Agreement was signed, gives an idea of the importance of this event in the history of the two churches.

The unity which was envisaged according to the agreement was "a new organically united reformed church, organised according to synodical presbyterial structures, which lives missionally and is committed to the biblical demands of love, reconciliation, justice and peace. ${ }^{30}$ It further stated that the two churches were committed to nonracialism, inclusiveness and the acceptance and celebration of the multicultural composition of the churches. In a separate paragraph the following important statement was made: "We agreed that the Belhar Confession will be part of the confessional basis of the reunited church." 31 The statement concluded: "We confess that our journey guided by the Memorandum of Agreement is a gift from God that we need to cherish so that the church can be a sign of the Kingdom of God and God's reconciliatory work in Christ through His Spirit in the world." 32

One of the important outcomes of the Memorandum of Agreement was the road map to church reunification. The road map consisted of 10 stages on the way to church reunification, with stage one indicated as the signing of the Memorandum of Agreement and stage 10 the constituting of the general synod of the Reunited Church. ${ }^{33}$ Plaatjies-

24 Accessedhttps://www.kerkargief.co.za/doks/acta/AS_Agenda_2013.pdf., p. 150. Accessed July 20, 2020.

25 "With Prof. Plaatjies-Van Huffel as moderator came a new attitude towards discussions on church unity." Remark to the author by one of the DRC delegates.

26 Discussions took place on 23-25 February 2012, 25-26 July 2012. Plaatjies-Van Huffel was part of these discussions as member of the Executive of URCSA.

27 The two churches were URCSA and the DRC.

28 The meetings took place before the signing of the agreement in April 2013.

29 https://www.kerkargief.co.za/doks/acta/AS_Agenda_2013.pdf., p. 162-165. Accessed July 23, 2020.

30 https://www.kerkargief.co.za/doks/acta/AS_Agenda_2013.pdf., p. 167. Accessed July 23, 2020.

31 https://www.kerkargief.co.za/doks/acta/AS_Agenda_2013.pdf., p. 167. Accessed July 23, 2020.

32 https://www.kerkargief.co.za/doks/acta/AS_Agenda_2013.pdf., p. 167. Accessed July 23, 2020.

33 https://www.kerkargief.co.za/doks/acta/AS_Agenda_2013.pdf., p. 170. Accessed July 23. 2020. 
Van Huffel, as church polity expert, not only played an important role in the development of the road map, but her knowledge was also instrumental in writing the Provisional Church Order. The dream of unity between the churches became a bigger reality after the general synod of the DRC approved an important proposal in October 2013, namely to make the Confession of Belhar a part of the confessional basis of the church $^{34}$ by changing Article 1 of its Church Order. Should the church succeed in doing that, one of the biggest stumbling blocks on the way to church reunification would be out of the way. The fact that Plaatjies-Van Huffel was part of the commission ${ }^{35}$ that wrote a new proposed Article 1 is also an indication of the important role that she played in the reunification process. ${ }^{36}$ According to the process, all 10 regional synods of the DRC had to approve the new Article 1 with a two thirds majority. Sadly, this did not happen, as was reported at the general synod of the DRC in October $2015 .{ }^{37}$ It meant that the reunification process had grinded to a halt.

Plaatjies-Van Huffel's reaction to this development clearly illustrates how important unity between the churches and the Confession of Belhar was to her. In her address at the 30th celebration of the Kairos document at the University of Johannesburg, she said: "History will judge the DRC severely on why they did accept the Confession of Belhar." ${ }^{38}$ She continued by saying that the DRC "could not see the favourable time of the Lord" and she believed that the church had not yet confronted its past. The DRC had to be brave and take a point of view on justice, reconciliation and unity. ${ }^{39}$ It was clearly the Confession of Belhar talking through Plaatjies-Van Huffel. Although she was dismayed by the decisions taken by the DRC, it did not keep her from playing an important role in the re-admission of the DRC to the World Council of Churches. The fact that she endorsed the process in her capacity as president for Africa and was part of a distinguished delegation, which consisted of Prof. Jerry Pillay, Dr Frank Chikane and Bishop Malusi Mpulwana of the South African Council of Churches (who were all present in Trondheim on 27 June 2016), confirms her commitment to the unity of the church. $^{40}$

\section{Social Justice}

A second important area of the Belhar Confession, which became evident through the work and life of Plaatjies-Van Huffel, was social justice. It is almost impossible and

34 https://www.kerkargief.co.za/doks/acta/AS_Notule_2013.pdf., p. 16. Accessed July 23, 2020.

35 Other members of the commission were: Dr Kobus Gerber, ds. Nelis Janse van Rensburg, ds. Godfrey Betha, Dr Leepo Modise, Prof. Piet Strauss, Dr Johan Ernst, Dr Quintus Heine, and Dr Chris van Wyk.

36 A further indication the important role which she played in the relationship between the two churches is the fact that it was the delegation form the DRC that proposed her as President for Africa at the General Assembly of the World Council of Churches in Busan, South-Korea in 2013.

37 https://www.kerkargief.co.za/doks/acta/AS_Agenda2_2015.pdf. P2 Viewed on 23 July 2020.

38 C. Mallovich, "NGK sal fel Geoordeel word oor Belhar." Die Burger, Donderdag 20 Augustus 2015, 3.

39 Mallovich, 3.

40 N. Jackson. https://kerkbode.christians.co.za/2016/06/27/ng-kerk-word-volle-lid-van-diewereldraad/. Accessed September 15, 2020. 
definitely beyond the scope of this article to describe everything that she had done in terms of social justice. A press statement which she wrote on the Marikana massacre serves as only one example of how important social justice was to her.

The Marikana massacre took place on 16 August 2012 when the South African Police Service opened fire on a crowd of striking mineworkers at Marikana in the North West province of South Africa. 34 mineworkers were killed; and 78 seriously injured. ${ }^{41}$ After the tragedy, the Marikana Commission of inquiry was set up. The report of the commission was submitted to President Zuma on 31 March $2015 .{ }^{42}$ On Marikana Memorial Day, 16 August 2015, URCSA released an important press statement. This statement was written by Plaatjies-Van Huffel. ${ }^{43}$

The statement started with an important question: "How should a church respond to the report and the tragic incident it refers to?" 44 Plaatjies-Van Huffel then quotes the words of the prophet in Lamentations 3, which is a song that calls for confession and a return to God as an answer to the question posed in the statement. The choice of this passage of scripture clearly indicates Plaatjies-Van Huffel's quest for social justice. It is further confirmed in a second important part of the statement, in which URCSA as a church called on all congregations and churches to use 16 August 2015 as a Marikana Memorial Day. The statement read:

Let us lament what has happened at Marikana. ${ }^{45}$

Let us reflect on what happened.

Let us do something so that it will not happen again.

It then quotes Lamentations 3:19-22:

19 I remember my affliction and my wandering, the bitterness and the gall.

20 I well remember them, and my soul is downcast within me.

21 Yet this I call to mind and therefore I have hope:

22 Because of the LORD's great love we are not consumed, for his compassions. ${ }^{46}$

Plaatjies-Van Huffel then quoted Article 3 of the Confession of Belhar:

As a confessing church we believe that God has entrusted to his Church the message of reconciliation in and through Jesus Christ; that the Church is called to be the salt of the earth and the light of the world, that the Church is called blessed because it is a

41 https://www.sahistory.org.za/article/marikana-massacre-16-august-2012. Accessed July 24, 2020.

42 https://www.sahistory.org.za/article/marikana-massacre-16-august-2012. Accessed July 24, 2020.

43 Confirmed and received via email form Dr Dawid Kuyler who was scribe of the General Synod of URCSA at that time.

44 URCSA Press Statement on Marikana, 1, 2015b.

45 URCSA Press Statement on Marikana, 1.

46 URCSA Press Statement on Marikana, 1. 
peacemaker, that the Church is witness both by word and by deed to the new heaven and the new earth in which righteousness dwells.

The statement proceeded by then quoting Article 4 of the Confession of Belhar:

As a confessing Church we have no other choice but to believe that God has revealed himself as the One who wishes to bring about justice and true peace among men; that in a world full of injustice and enmity He is in a special way the God of the destitute, the poor and the wronged and that He calls his Church to follow Him in this; that He brings justice to the oppressed and gives bread to the hungry; that He frees the prisoner and restores sight to the blind; that He supports the downtrodden, protects the stranger, helps orphans and widows and blocks the path of the ungodly; that for Him pure and undefiled religion is to visit the orphans and the widows in their suffering; that He wishes to teach His people to do what is good and to seek the right; that the Church must therefore stand by people in any form of suffering and need, which implies, among other things, that the Church must witness against and strive against any form of injustice, so that justice may roll down like waters, and righteousness like an ever-flowing stream; that the Church as the possession of God must stand where He stands, namely against injustice and with the wronged; that in following Christ the Church must witness against all the powerful and privileged who selfishly seek their own interests and thus control and harm others. ${ }^{47}$

The press statement concluded with the following remark: "Based on our confession that God has called us to reconciliation and justice, we call on all congregations of URCSA and all other churches to observe with us 16 August 2015 as Marikana Memorial Day." This press statement confirms how important the application of the Belhar Confession in church and society was to Plaatjies-Van Huffel. She took the important message of the Confession serious and applied it on behalf of URCSA to one of the most tragic events in post-apartheid South Africa's recent history. To her, the Confession of Belhar was apart from scripture, the most important lens through which she viewed church and society. It also motivated her actions and her words. Her contribution and leadership were also recognised when she received the Premier's Commendation Certificate from the Premier of the Province of Western Cape, in terms of section 2 of the Western Cape Provincial Honours Act, 1999 (Act 9 of 1999), for work amongst the impoverished in the Robertson area, in $2004 .{ }^{48}$

An open letter on women's and children's rights, addressed to the president of South Africa, dated 1 March 2020, shows the heart of somebody who lived social justice. She wrote: ${ }^{49}$

Dear Mr President

For all victims of femicide and child murders, an ode

47 URCSA Press Statement on Marikana, 2.

$48 \mathrm{https} / / /$ sun.academia.edu/MaryAnnPlaatjiesvanHuffel/CurriculumVitae.

49 The whole letter is quoted because only parts of it will not do justice to the purpose and the content. 
Dear Mr President, how long should the long walk to freedom be if it cost you only eight little steps to buy an ice-cream across the street to meet your lynch man.

How long should the long walk to freedom be?

If you cannot trust the uncle across the street, the next-door neighbour, the male friend who frequents your house, your niece, your own brother.

How long?

How long should the long walk to freedom be?

If leaving the safety of your house to relieve yourself at the back of your yard in the middle of the night might cost your death,

If leaving your house to pick up a parcel at the post office might mean the end of your studies,

If walking home after school because the government-funded school bus abandoned, you might mean that your body will be found wasted alongside the road.

How long?

We the people of South Africa are tired of hearing stories of mutilated female bodies, decomposed female bodies, dismembered bodies.

We lament what South Africa is becoming ... a slaughterhouse of women and children. Women and children are not free in this beautiful country of ours.

They are imprisoned by the lustful gaze of those who are lurking in the streets to take what does not belong to them.

Their movements are restricted by those who are prowling on them,

Who is guarding women and children against the thousands of paedophiles, rapists and murderers who are freely roaming our streets?

Who is barricading us against the onslaught on women and children?

Tazne van Wyk, it took you eight little steps ... may these steps signal the end of the scourge against women and children.

Hear the wailing in the land, Mr President

Our children are no more:

"Rachel is weeping for her children; she refuses to be comforted because of her children, for they are no more." (Jeremiah 31:15)

Mary-Anne Plaatjies-Van Huffel. ${ }^{50}$

\section{Reconciliation}

The third important focus area of the Confession of Belhar is reconciliation. PlaatjiesVan Huffel devoted a large part of her life and work to reconciliation. Again, it is impossible to write about everything she did. One of her most important contributions was on the difficult issue of xenophobia, which emerged in South Africa during the last decade.

Xenophobia became a serious problem during 2008 when xenophobic attacks took place all over South Africa. 67 people were killed and many foreigners in the country were robbed of their livelihood and became homeless. ${ }^{51}$ Plaatjies-Van Huffel was outspoken on the issue of xenophobia. She believed that the church and, therefore, all believers,

50 https://www.facebook.com/maryanneplaatjiesvanhuffel. Accessed September 15, 2020.

51 Mary-Anne E. Plaatjies-Van Huffel, “"n Nuwe Hart Staan Oop vir Vreemdelinge” Die Kerkbode, 7 Junie 2013, $190(9,6)$. 
were called to acts of reconciliation towards foreigners. In an important indication of her stance on this issue, published in Die Kerkbode under the heading, ' $n$ Nuwe Hart Staan Oop vir Vreemdelinge (A New Heart Stands Open to Foreigners) she referred to Mathew 25:31-46 and clearly stated that Jesus demanded hospitality and love to foreigners. She further stated that the church had to embody what God did through his Son, Jesus Christ, by being the agent of reconciliation between all peoples. ${ }^{52}$

The re-occurrence of xenophobic attacks in 2015 led to an important press statement issued by URCSA on 16 April $2015 .{ }^{53}$ Although the statement was issued on behalf of URCSA, Plaatjies-Van Huffel drafted the original statement. In the statement URCSA called on the South African government to confront the rising tide of racism, ethnocentrism and xenophobia in South Africa. It stated further: "The wider issues at stake are how to handle difference, respond to the 'other,' and negotiate plurality." Firm action was called for from government, and URCSA urged all South Africans and people across the globe to acknowledge "others" in their difference and to welcome strangers even if their "strangeness" was sometimes threatening. Most important is the following remark, which forms the foundation of the statement in which URCSA called for reconciliation: ".. even with those who have declared themselves our enemies. ${ }^{55}$

The statement then continued by a call to the church and quoted Article 3 of the Belhar Confession, which states: "We believe in the words of the Belhar Confession (Article 3) that God has entrusted to his Church the message of reconciliation in and through Jesus Christ; that the Church is called to be the salt of the earth and the light of the world; that the Church is called blessed because it is a peacemaker, that the Church is witness both by word and by deed to the new heaven and the new earth in which righteousness dwells." texts, making it clear that the "Bible emphasizes that strangers or refugees should be met with friendliness and caring." 57

The statement continued by quoting Article 4 of the Confession of Belhar which states: "We believe that God has revealed himself as the One who wishes to bring about justice and true peace among men; that in a world full of injustice and enmity He is in a special way the God of the destitute, the poor and the wronged and that He calls his Church to follow Him in this ..."58 The following words in the statement expose the heart of the author of the statement: "We believe that the triune God called us together on earth to share our common humanity. God called us to embody Christ's work of reconciliation

52 Plaatjies-Van Huffel, 6, 2013.

53 Although the statement was signed by the scribe of the executive of URCSA, Dr D Kuyler, it was drafted by Plaatjies-Van Huffel.

54 Press Statement URCSA 16 April 2015a. "Press Statement: Uniting Reformed Church in Southern Africa (URCSA) against Xenophobia." Personal correspondence of author.

55 URCSA Press Statement against Xenophobia, 1.

56 URCSA Press Statement against Xenophobia, 1.

57 URCSA Press Statement against Xenophobia, 1.

58 URCSA Press Statement against Xenophobia, 2. 
toward fellow human beings notwithstanding race, culture or creed." ${ }^{\prime 59}$ It continues by describing Christian hospitality as seeing the "other" not as a threat but as a "gift." "When the 'other' comes to our country, we are challenged to share these gifts with them, in thankfulness to God. Those who come as aliens are to be received kindly and treated as one of our own people" (Deuteronomy 26:5-8; Exodus 22:21-7; Leviticus 19:33-34). ${ }^{60}$ The statement concluded by urging all to "pursue community with one another, to fight against all who threaten or hinder this common humanity." ${ }^{61}$ It then stated that God cared for everyone and regarded each individual human as being infinitely valuable and then: "We therefore reject xenophobia and Afrophobia."

The press statement again shows how the Confession of Belhar played a vital role in how Plaatjies-Van Huffel looked at society. It also guided her thoughts and her words in such a way that she personified the Confession. There are also other examples, like the fact that she signed the "Punta del Este Declaration on Human Dignity for Everyone Everywhere" as a delegate to the Africa Consortium of Law and Religion Conference hosted in Botswana 2019, which confirms how important reconciliation was to her.

\section{Conclusion}

"On the Confession of Belhar she said straight forward that it is not possible to discuss church re-unification without putting the Confession of Belhar in the centre of the debate. Her point of view was that the central themes of the Confession of Belhar, namely unity, justice and reconciliation were important to reformed Christians all over the world." 63 "It can also be used to address the problems in post-apartheid South Africa, for example the exclusion of others on the grounds of race, language, culture, gender, irreconcilability, injustice, economic injustice, corruption, etc." ${ }^{64}$ Her point of view was that the Confession was never aimed at a specific race, language or culture group or period. She was convinced that the Confession transcends time and addresses other contexts.

These above words of Jean Oosthuizen (2020, In Memoriam, Litnet) sum up how important the Confession of Belhar was to Plaatjies-Van Huffel and how it directed her life. She will be remembered as somebody who did only talk about the Confession of Belhar, but who lived it.

59 URCSA Press Statement against Xenophobia, 2.

60 URCSA Press Statement against Xenophobia, 2.

61 URCSA Press statement against Xenophobia, 2.

62 URCSA Press Statement against Xenophobia, 2.

63 J. Oosthuizen, "Plaatjies-Van Huffel se Dood Laat VGK Arm Agter. In Memoriam 2020 -05-21." Accessed July 26, 2020. https://www.litnet.co.za/plaatjies-van-huffel-se-dood-laat-vgk-arm-agter/.

64 Oosthuizen, 2020, 1. 


\section{References}

Flaendorp, C. 2014. "The Life and Times of Professor Mary-Anne Plaatjies-Van Huffel: A Transformative Church Leader in Sub-Saharan Africa." Studia Historiae Ecclesiasticae 40 (1) [cited 2020-07-20], 53-63. http://www.scielo.org.za/scielo.php? script=sci_arttext\&pid=S1017-04992014000200005\&lng=en\&nrm=iso. ISSN 2412-4265.

Kgatla, S. T. 2013. "The Belhar Confession Yesterday, Today and Tomorrow.” Accessed August 28, 2013. www.ngkok.co.za.

Jackson, N. 2016. "NG Kerk word Volle Lid van Wêreldraad.” Die Kerkbode 27 Junie 2016. Accessed September 15, 2020. https://kerkbode.christians.co.za/2016/06/27/ng-kerk-wordvolle-lid-van-die-wereldraad/.

Mallovich, C. 2015. Die Burger. "NGK sal fel Geoordeel word oor Belhar.” Donderdag 20 Augustus 2015.

NGK. Accessed July 20, 2020. https://www.kerkargief.co.za/doks/acta/AS_Agenda_2013.pdf., p. 150.

NGK. Accessed July 23, 2020. https://www.kerkargief.co.za/doks/acta/AS_Notule_2013.pdf., p. 16.

NGK. Accessed July 23, 2020. https://www.kerkargief.co.za/doks/acta/AS_Agenda2_2015.pdf., p. 2.

Nederduitse Gereformeerde Sendingkerk. 1982. https://www.kerkargief.co.za. Skema van Werksaamhede.

Oosthuizen, J. 2012. "Die Vrou met Leeuemoed Lei die VGK." Die Kerkbode, 19 Oktober 2012. https://doi.org/10.7328/jurpcb20122710167.

Oosthuizen, J. 2020. "In Memoriam 2020 -05-21 Plaatjies-Van Huffel se Dood Laat VGK arm agter.” Accessed July 26, 2020. https://www.litnet.co.za/plaatjies-van-huffel-se-dood-laatvgk-arm-agter/.

Plaatjies-Van Huffel, Mary-Anne E. 2013. “"n Nuwe Hart Staan Oop vir Vreemdelinge.” Die Kerkbode, 7 Junie 2013190 (9).

Plaatjies-Van Huffel, Mary-Anne E. 2014. "The Belhar Confession is its Historical Context." NGTT 55 (1). https://doi.org/10.5952/55-1-2-527.

Plaatjies-Van Huffel, Mary-Anne E. 2020. “Curriculum vitae.” Accessed September 16, 2020. https://sun.academia.edu/MaryAnnPlaatjiesvanHuffel/CurriculumVitae.

Plaatjies-Van Huffel, Mary-Anne E. Accessed July 20, 2020.

http://www.sun.ac.za/english/Lists/news/DispForm.aspx?ID=7366. 
“SA History.” Accessed July 24, 2020. https://www.sahistory.org.za/article/marikanamassacre-16-august-2012.

Theology/Corporate Communication 19/05/2020. "SU Mourns Passing of Prof. Mary-Anne Plaatjies-Van Huffel.” Accessed September 15, 2020. https://www.facebook.com/maryanneplaatjiesvanhuffel.

Uniting Reformed Church in Southern Africa. "Confession of Belhar.” www.vgksa.org.za.

Uniting Reformed Church in Southern Africa. "Confession of Belhar, Accompanying Letter." Accessed and copied August 24, 2013. www.vgksa.org.za.

Uniting Reformed Church in Southern Africa. 2015a. 16 April. "Press Statement: Uniting Reformed Church in Southern Africa (URCSA) against Xenophobia."

Uniting Reformed Church in Southern Africa. 2015b. 16 August 2015. "Press Statement on Marikana."

Van der Merwe, J. M. 2020. Pictures of the Original Text of the Confession of Belhar. Personal collection. 